\title{
Investigation of IFC file format for BIM based automated code compliance checking
}

\author{
Bayram Ali Temel $^{*}$ iD, Hasan Basri Başağa iD \\ Karadeniz Technical University, Civil Engineering Department, 61080, Trabzon, Turkey
}

\begin{abstract}
In the architecture, engineering, and construction (AEC) industry, a large number of laws and regulations define the technical features and standard requirements of a building. Checking the suitability of the building according to the rules in the building legislation is a human-oriented manual process that is largely based on 2D drawings. Therefore, this process is cumbersome, time consuming and error prone. Today, the use of Building Information Modeling (BIM) in the AEC sector continues to increase day by day. In a BIM-based construction project, digital models with 3D geometric and semantic information describe the building to be built extensively. This digital database prepared for the building can also be used to improve and partially automate the code compliance checking process. For this purpose, this data is exported with the Industry Foundation Classes (IFC) file format, and this IFC file format provides an excellent opportunity to automate the process of checking compliance. In this study, the IFC file format, which allows BIM-based buildings' automatic code compliance checking to be performed is examined, and the meanings of the codes in the IFC file of the sample building model are examined in detail by matching them with the model. In addition, it is explained how to filter the data of the building model required for conducting conformity control from the IFC file. It is also shown how to check the compliance of storey height values of the sample building model designed within the scope of the application according to the relevant regulation rules. As a result of the examinations, data that would automatically ensure code compliance checking can be obtained from the IFC file format and the relationship of the IFC file structure with automatic code compliance checking has been revealed.
\end{abstract}

\section{Keywords}

Construction industry; BIM; IFC; Automated checking system; Automated code compliance checking

Received: 18 May 2020; Accepted: 25 June 2020

ISSN: 2630-5771 (online) @ 2020 Golden Light Publishing All rights reserved.

\section{Introduction}

In the AEC sector, a great number of laws and regulations define the technical features and standard requirements of a building. A construction project has a wide range of legal regulations covering different engineering and architectural disciplines at each stage. Depending on international, national, or regional legislation, regulations should not only be followed by architects, engineers, and planning consultants during design activities, but also by administrative control authorities [1]. The structures designed as a result of all these legal restrictions and rules are subject to the conformity control and approval process in terms of legislation.

\footnotetext{
* Corresponding author

Email: bayram_ali_temel@hotmail.com
} 
In general, law and / or regulation explains the rules of practice regarding the design and construction phases of a building and requires compliance with the specified numerical limitations. Despite the large spending and technical improvements in the construction industry, the control of conformity of designed structures to the regulations requires a great deal of manual and high effort and excessive time [2]. In the event of a change in the design of the building, these control procedures lead to re-checks of the affected elements. With the manual control process, it is very likely that building approval checks will be carried out again due to the problems and reasons that may arise at any stage of a project from the check phase to the control phase. As a result, reapproval checks cause project delays and increased monetary costs of stakeholders associated with the process.

Today's digital developments provide an opportunity for the approval of the designed structure to be based on the automation system of conformity approvals from the relevant administrations. The increasing adoption of BIM, which now initiates a digital transformation in the AEC sector, introduces technological new tools to improve and partially automated building code compliance checking processes [1, 3]. One of these tools is the IFC file format, which contains detailed digital data of the model of the building designed in a BIM-based program, allowing data exchange between BIM programs [3].

In this study, the IFC file format, which enables the automatic code compliance checking of a building designed with a BIM based program, is examined. There are many rules in building legislation that the buildings must comply with during the design phase. These rules based on the laws and regulations are regulated by official administrations. Compliance checks of the designed buildings are mostly done manually.

BIM technology allows possibility to automatic control of the designed building's compliance with regulations. This can be done with IFC file format, which contains a lot of information about the building designed based on BIM. This information in the IFC file can be taken out of the file with the codes written in different languages $(\mathrm{C}++$, Matlab, ...) and compliance checks can be done with the rules in the legislation.

The main purpose of this study is to show that the information of the building in the IFC file is suitable for use in automatic code compliance checking. Besides, in the study, the location of the information of the designed building in the IFC file and how it can be obtained from the file is demonstrated.

\section{2. . Building Information Modeling (BIM)}

BIM is a global digital technology that revolutionizes the construction industry and is believed to have the potential for new changes [4]. BIM has been an important innovation in the design process to cover the lack of coordination between different engineering disciplines and architects [5]. Based on the information-rich 3D model, BIM is seen as an important improvement and easiness over the traditional CAD approach (Fig. 1) [6, 7].

BIM contains all the geometry, spatial relations, geographic information, property information of the building elements altogether. It can also store analysis and modeling results. In addition, any information related to the life cycle of a building can be defined and stored in BIM [8]. BIM is a system where a lot of the information of the designed model is stored in three dimensions and digitally. Apart from common and general information, information can be added to BIM, which operates as a single database, by the participants. In addition, participants can access this database whenever and wherever they want [9].

BIM is used in project management [10-13], facility management [14-19], green and sustainable buildings [20-26], geographical information systems [27-30], automation systems [31-33], rule control systems [34-37].

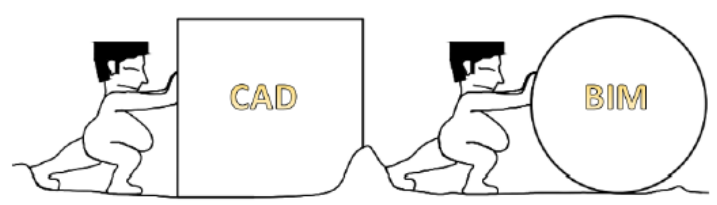

Fig.1. CAD and BIM [7] 
The adoption and implementation of BIM in the architecture, engineering, construction, and operation (AECO) industry is gradually increasing [38, 39].

With the development of BIM modeling software tools (Autodesk Revit, Nemetschek Allplan, Vectorworks, Graphisoft Archicad, Bentley MicroStation, BricsCAD BIM, Trimble Tekla Structures, etc.) the virtual counterparts of the structures are built closer to the reality. Thanks to this reality, improvements are made in design decisions, better coordination between project stakeholders, and manufacturing errors are reduced. Thanks to better planning, it is possible to take early measures against cost, time gains, and negativity. The BIM process is the process that runs from the design phase of the structure to the completion of its life, and the better the modeling process, which is the first step in this chain, the more efficient the other stages will be [40].

These developments in BIM technology offer opportunities for new software tools that can control compliance with automatic code and are a prerequisite for these systems [41, 42]. Integrating BIM into the control of building codes is an important step in these developments. It will also increase the efficiency and accuracy of control processes for designers and administrative institutions [43]. Thus, in the future, BIM will become a digital asset that is important not only in design but also for obtaining approval from legal institutions [44].

\section{Automated code compliance checking}

Major and important steps in the field of automated code compliance checking took place after the emergence of the IFC open data format for BIM $[45,46]$. Since the IFC file format contains detailed information on each element of the building designed, this information can be arranged and controlled by rule control systems.

Regarding the construction industry, the first successful effort to automate design alignment began with the study of the implementation of decision tables representing the standard features of Fenves [47] and the American Institute of Steel
Construction (AISC). Later, Lopez et al., who implemented Fenves' the Standards Interface for Computer Aided Design (SICAD) system, tried to improve the research on this subject $[48,49]$. Next, many research studies on the subject of Automated Code Compliance Checking have been done until today [45, 46, 50-53].

Most of the research carried out within the scope of the subject of automatic code compliance consists of studies on Automated Code Compliance Checking systems [54-59]. Some of these systems are considered to be "black box methods," where users have very limited access to the rule creation engine. Others are "gray box or white box methods," where users have varying degrees of customization and interaction [43].

An automated code compliance checking system is a computational procedure for addressing the manual regulation verification problem in a finite number of computable steps. Systems developed for automatic code compliance control generally consist of four stages. The first stage consists of interpreting and developing the rules in the legal legislation and logical regulation of the rules in the legislation for their implementation. In the second stage, data is produced for the building model to be inspected. This data generation is created by a BIM-based program. At this stage, the necessary rules are started to be checked. The third stage is the stage where the compliance check is performed, which realizes the true rule compliance verification. The last step is to report the compliance check results [43]. Some of the systems developed for an automated code compliance checking are Corenet System, Solibri Model Checker (SMC), Jotne Edmmodelchecker, Norwegian Statsbygg's Design Rule Checking Efforts, International Code Council, Us General Services Administration Design Rule Checking, Australia's Designcheck and Portugal's Lica System.

\section{Industry Foundation Classes (IFC)}

Since the early 1970s, two-dimensional CAD programs have been used to represent building components. In the early 1990s, building model 
demonstrations began to shift to the object-based BIM paradigm [60]. CAD programs have been transformed into systems that can make threedimensional (3D) designs through BIM programs (AutoCAD, ArchiCAD, Revit, etc.) [61]. However, the BIM process has started to fundamentally change the AEC industry. The emergence of the BIM concept, together with the IFC open data format specification for building components, provided a standard method for a computable representation of a building and a generally agreed protocol [43]. After the emergence of the IFC open data format for BIM, major steps have been taken in the field of automated code compliance checking $[45,46]$.

IFC is a standard object-based structure data model developed by the Industry Alliance for Interoperability (IAI) in 1994 [62, 63]. IAI was renamed BuildingSMART in 2005. IFC specifications are developed and updated by BuildingSMART. In 2013 IFC was registered with the International Standardization Organization as ISO16739 'IFC for data sharing in the construction and facility management industries'. In general, IFC is a standardized, digital description of the built environment, including buildings and civil infrastructure. It is an open, international standard [64], meant to be vendor-neutral, or agnostic, and usable across a wide range of hardware devices, software platforms, and interfaces for many different use cases [65]. According to BuildingSMART International [66], IFC is defined as "an open specification for BIM data that is exchanged and shared among the various participants in building construction or facility management project."

IFC is a standard, object-based data model developed in EXPRESS language regardless of any software [66, 67]. EXPRESS is a conceptual chart language that provides a description of the classes of certain areas, information, or qualities (walls, columns, beams, etc.) related to these classes and restrictions in these classes [43]. The IFC scheme is also known as the international standard ISO/IS 16739 [64].
IFC represents a set of internationally standardized object definitions for each model of a project created with a BIM-based program [43]. Objects are also called building elements used in the building project. These building elements are three-dimensional and have characteristics such as definition, name, size, location, material, cost, etc.

IFC is supported by BIM-based software. It is often used to exchange information from side to side for a particular business transaction [65]. The IFC scheme has been designed to facilitate effective data sharing between AEC parties and asset managers. The benefit of using the IFC scheme is that information can be shared in a way that enables and promotes interoperability. In particular, IFC enables AEC data to be shared among engineers, architects, construction companies, and asset managers [68]. Fig. 2 provides an example of some data sharing features possible thanks to the IFC scheme.

\subsection{IFC file formats}

IFC defines multiple file formats that can be used by supporting various encodings of the underlying data. IFC files can be exchanged between software products, along with the file formats ".ifc", ".ifcXML" and ".ifcZIP". Information about the IFC file formats is given in Table 1.

\subsection{IFC versions (schema)}

Today, versions of the different IFC schemes have been published since 1996 to improve information exchange and interoperability within the AEC industry. The schema versions of the IFC published by year are shown in Table 2 .

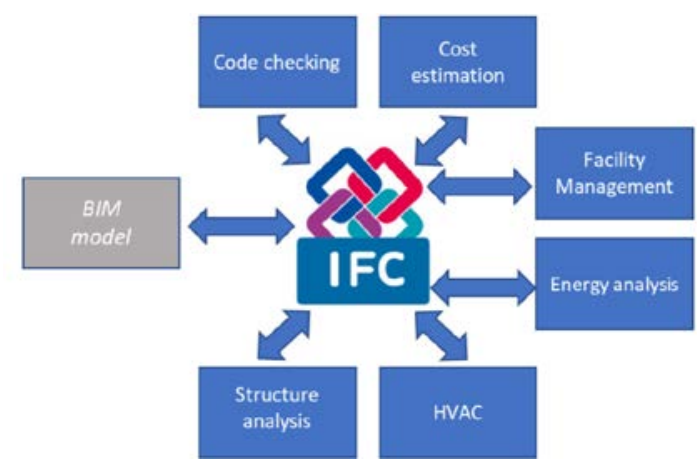

Fig. 2. An example of interoperability advantages associated with the IFC scheme [68] 
Table 1. Information on IFC file formats [69, 70]

\begin{tabular}{|c|c|c|c|}
\hline File Format & Extension & Size & Summary \\
\hline IFC-SPF & \multirow{4}{*}{.ifc } & \multirow{4}{*}{$100 \%$} & $\begin{array}{l}\text { - SPF or IFC-SPF is the most widely used format for IFC in } \\
\text { practice, which is the most compact of the formats listed that } \\
\text { can be read as text. }\end{array}$ \\
\hline $\begin{array}{l}\text { (SPF:STEP } \\
\text { Physical File) }\end{array}$ & & & - IFC-SPF is based on the ISO standard for clear text \\
\hline \multirow{2}{*}{$\begin{array}{l}\text { (STEP: } \quad \text { Standard } \\
\text { for the Exchange of } \\
\text { Product } \quad \text { Model } \\
\text { Data) }\end{array}$} & & & $\begin{array}{l}\text { - IFC-SPF is a text format, where each line typically consists of } \\
\text { a single object record, and having file extension ".ifc". }\end{array}$ \\
\hline & & & $\begin{array}{l}\text { - This is the most widely used IFC format, having the advantage } \\
\text { of compact size yet readable text. }\end{array}$ \\
\hline \multirow{3}{*}{$\begin{array}{l}\text { IFC-XML } \\
\text { (XML: Extensible } \\
\text { Markup Language) }\end{array}$} & \multirow{3}{*}{.ifcXML } & \multirow{3}{*}{$113 \%$} & $\begin{array}{l}\text { - IFC-XML is an XML format defined by ISO 10303-28 } \\
\text { ("STEP-XML"), having file extension ".ifcXML". }\end{array}$ \\
\hline & & & $\begin{array}{l}\text { - This format is suitable for interoperability with XML tools and } \\
\text { exchanging partial building models. }\end{array}$ \\
\hline & & & $\begin{array}{l}\text { - Due to the large size of typical building models, this format is } \\
\text { less common in practice. }\end{array}$ \\
\hline \multirow[t]{2}{*}{ IFC-ZIP } & \multirow[t]{2}{*}{.ifcZIP } & \multirow[t]{2}{*}{$17 \%$} & $\begin{array}{l}\text { - IFC-ZIP is a ZIP compressed format consisting of an } \\
\text { embedded IFC-SPF file or IFC-XML file and having file } \\
\text { extension ".ifcZIP". }\end{array}$ \\
\hline & & & $\begin{array}{l}\text { - Compressed IFC files with much smaller file size; can be read } \\
\text { by most software applications that support IFC. }\end{array}$ \\
\hline
\end{tabular}

Table 2. IFC schema versions by years [71]

\begin{tabular}{|c|c|c|c|c|c|c|c|c|c|c|c|c|c|c|c|c|}
\hline Name & & 芜 & 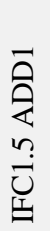 & ํㅓㄹ & 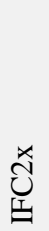 & 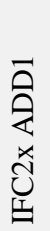 & 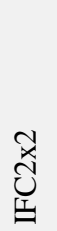 & 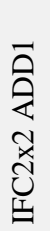 & শ્ત્ય & 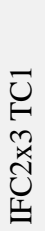 & 导 & 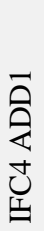 & 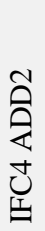 & 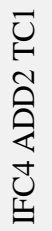 & 苞 & 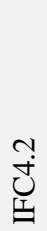 \\
\hline (уууу-mm) & 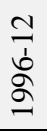 & 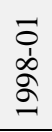 & $\begin{array}{l}\infty \\
0 \\
1 \\
\infty \\
\text { Sి } \\
\text { న్ }\end{array}$ & $\begin{array}{l}\text { 어 } \\
\text { 혀 } \\
\text { જે }\end{array}$ & 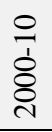 & $\begin{array}{l}\stackrel{0}{1} \\
\stackrel{1}{1} \\
\stackrel{0}{8} \\
\stackrel{2}{v}\end{array}$ & 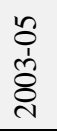 & $\begin{array}{l}\hat{O} \\
\stackrel{1}{+} \\
\text { ঠे }\end{array}$ & $\begin{array}{l}\text { ㄱ } \\
\text { ப் } \\
\text { ठำ }\end{array}$ & 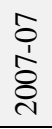 & 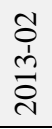 & 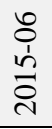 & 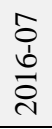 & $\begin{array}{l}\stackrel{ }{1} \\
\stackrel{1}{ } \\
\stackrel{ }{\circ}\end{array}$ & 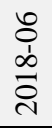 & 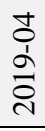 \\
\hline
\end{tabular}

The selection of the IFC file scheme is very important in defining the content and structure of the IFC file, and therefore it should be coordinated and selected according to its intended use. Current versions [72]:

- IFC4 (still in beta, certification process in progress, offers certain advanced possibilities but is not widely supported yet),

- IFC2x3 (currently the most supported and stable format, certified in Revit and recommended for production),
- IFC2x2 (recommended if the recipient of the file does not have software with IFC2x3 or IFC4 support).

\subsection{IFC structure}

The information of the building elements of the models created with BIM programs can be easily transferred between different software thanks to the IFC file format and BIM-based programs. When the BIM model is converted to IFC format, the information of the building elements is translated into the relevant IFC concepts. All definitions and 
descriptive information of IFC are regularly updated and developed by BuildingSMART [73]. When the BIM model is converted to IFC file format, detailed information required for automatic code compliance control is provided. IFC data file is created by exporting from BIM based program. Similarly, an IFC file can be opened with a BIM based program. Fig. 3 shows how to export the IFC file format of the model created with the Autodesk Revit program and how to open any IFC file. These created IFC files can be opened and viewed with a text editor program such as Microsoft Notepad.

The IFC schema defines how plain texts are turned into object aggregates with relations and type inheritance [74]. That's what the schema is, it's like a big map where everything has its own dedicated place. At a very simple level, the IFC schema is made up of three main items. These are given in Fig. 4 [75].

Entities: They are like the main nodes of the IFC scheme. IFC defines an EXPRESS-based entity-relationship model that consists of hundreds of entities arranged in an object-based hierarchy. Each asset is identified by naming it after the "Ifc" prefix (e.g., IfcBeam, IfcSpace, IfcBuilding). An IFC entity is an object uniquely identified in the IFC data model. Depending on the entity definition, the object is assigned certain default attributes and dependencies within the IFC schema. Each asset in IFC is described in detail in the Data Dictionary prepared by BuildingSmart. There are 412 current assets defined in the Data Dictionary of BuildingSmart [76]. They can be a building element entity (IfcWall), an entity that regulates the relationships between elements (IfcRelAggregates, IfcRelAssigns, etc.) or an asset that contains the properties of these elements (IfcRelDefinesByProperties). A threedimensional section of an exemplary building model created with a BIM program is given in Fig. 5. The names of the corresponding to the IFC entities of each element forming the model are also shown on the model given in the Fig. 5.

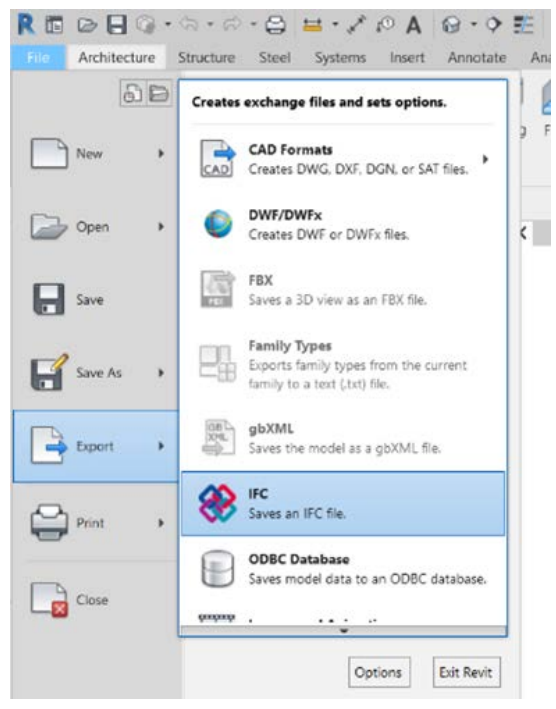

(a)

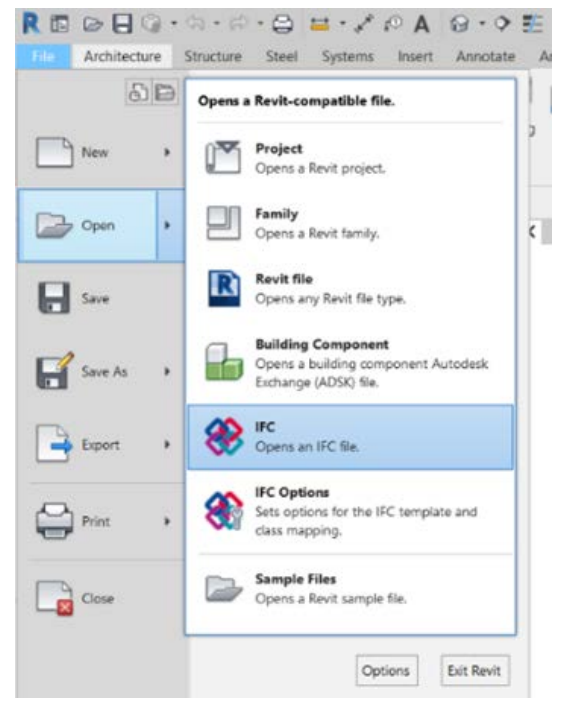

(b)

Fig. 3. (a) Exporting and (b) opening the IFC file in Autodesk Revit program

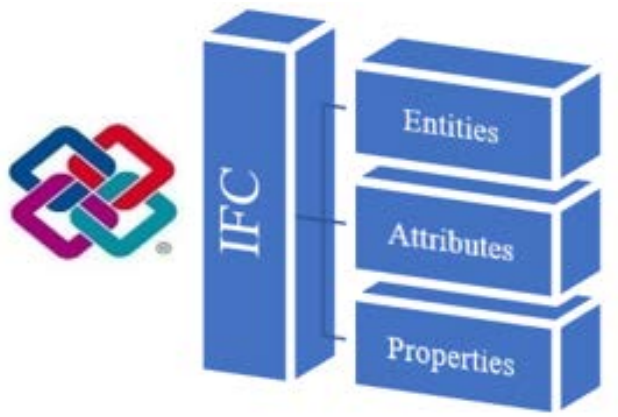

Fig. 4. Basic IFC components [75] 


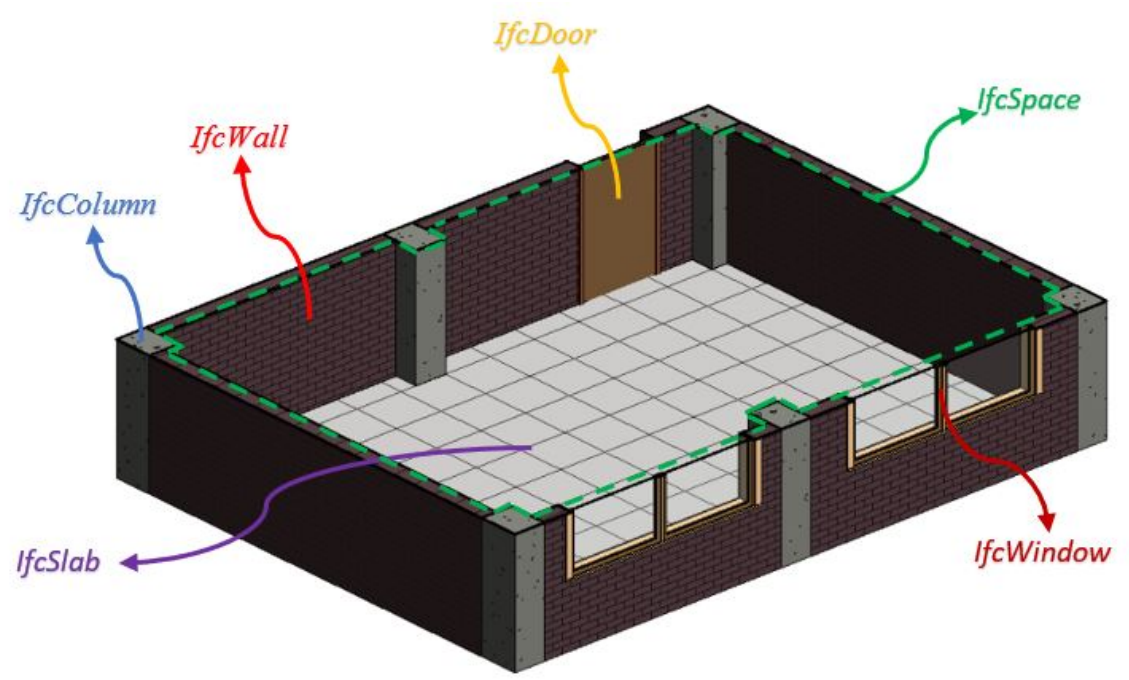

Fig. 5. Example of IFC entities on the model

Attributes: It is defined as information within an entity defined by reference to a particular entity. There are three kinds of attributes: direct attributes, inverse attributes and derived attributes. These vary between entities, but the first four attributes and definitions that each entity has are as follows [76]:

1. GlobalId: Assignment of a globally unique identifier within the entire software world,

2. OwnerHistory: Assignment of the information about the current ownership of that object, including owning actor, application, local identification and information captured about the recent changes of the object,

3. Name: Optional name for use by the participating software systems or users,

4. Description: Optional description, provided for exchanging informative comments.

Properties: For element-based entities, there is an attribute called HasPropertySets. This allows a property set (a group of properties) to be assigned to the entity. Within this property set are the individual properties, which describe the entity further or describe its performance. In the schema, there are already defined property sets and properties. Example for the entity "IfcColumnType" the property set is
"Pset_ColumnCommon" and property is "FireRating” [75].

\section{Methodology}

In this study, a simple building example model is designed in BIM based Autodesk Revit v2020 program. As the level of detail of the design increases, the content volume of the IFC data file increases in direct proportion to the level of detail. In order to make the IFC file of the sample application model more easily examined and perceptible, LOD 200 was preferred as the level of detail in model. Later, the IFC file was created by exporting this sample building model's information from the Autodesk Revit v2020 program. This file is preferred in the scheme IFC $2 \times 3$ (currently the most supported and stable format, certified in Revit and recommended for production [72]). Finally, the meanings of the codes in this IFC file are examined by matching them with the model. Then, a way of how this data should be filtered out of the IFC file is shown to demonstrate the usability of the data of the building model in the IFC file for code compliance checking. In addition, it was shown where and how the IFC file structure contains the necessary data in the file for code compliance checking. Finally, how to make the code compliance checks of the floor height values of the sample building model designed within the scope of 
the application according to the rules in the related regulation are explained in detail.

\section{Implementation}

In order to analyse the IFC file in detail, a simple building project was modeled at the LOD 200 level with the Autodesk Revit program. The building consists of 2 floors (Storey 1 and Storey 2) and 4

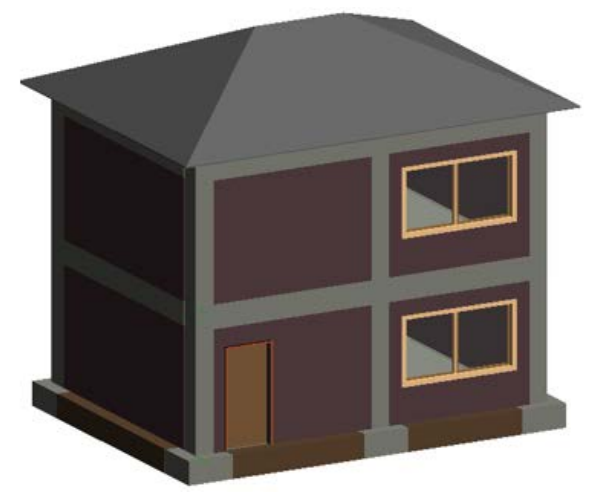

(a) 3D view 1

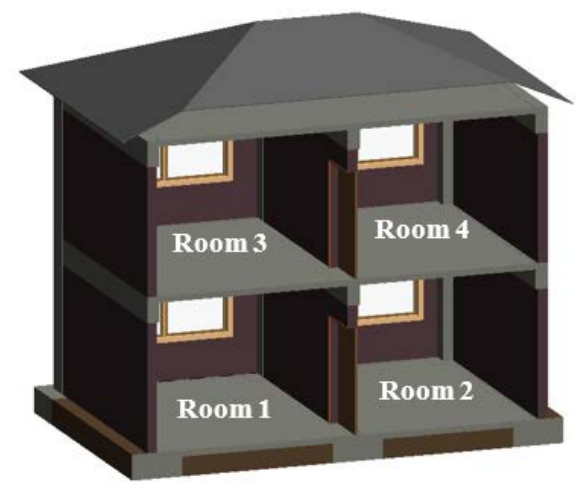

(C) 3D cutaway view 1

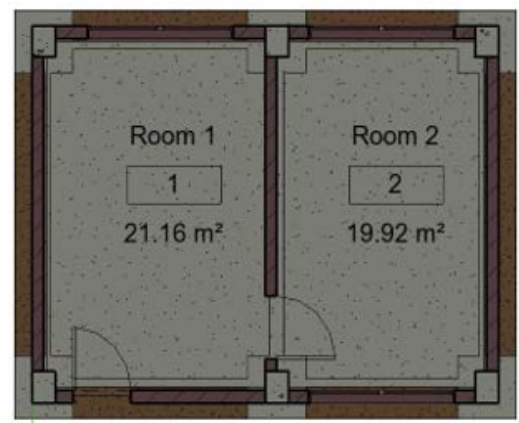

(e) First floor plan rooms (Room 1, 2, 3, and 4). 3D view, 3D sectional view, and floor plans of this building are given in Fig. 6.

The sample building model created with Revit was exported in 2x3 schema version and with an ".ifc" extension. A view of the plain text content obtained when opened in this way by the Microsoft Notepad program of the IFC file is given in Fig. 7.

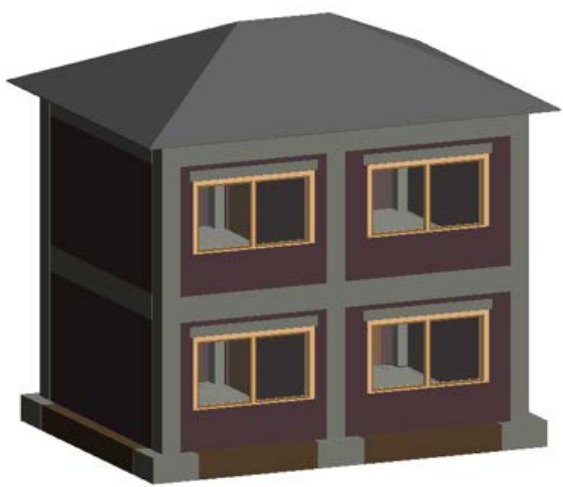

(b) 3D view 2

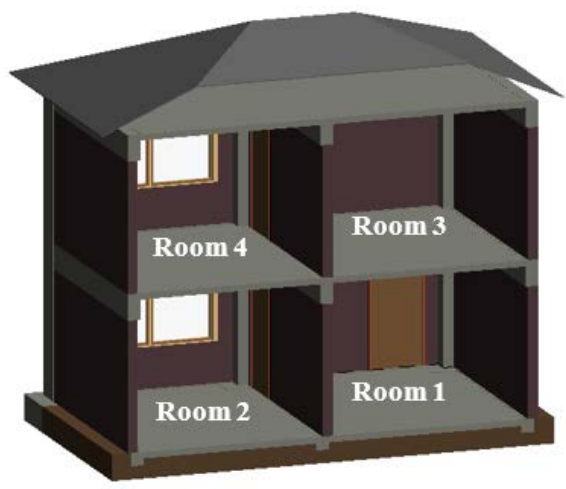

(d) 3D cutaway view $22 \mathrm{t}$

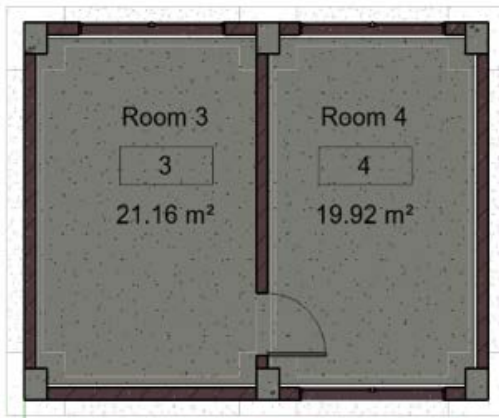

(f) Second floor plan

Fig. 6. 3D views, 3D section views and floor plans of the sample building project 


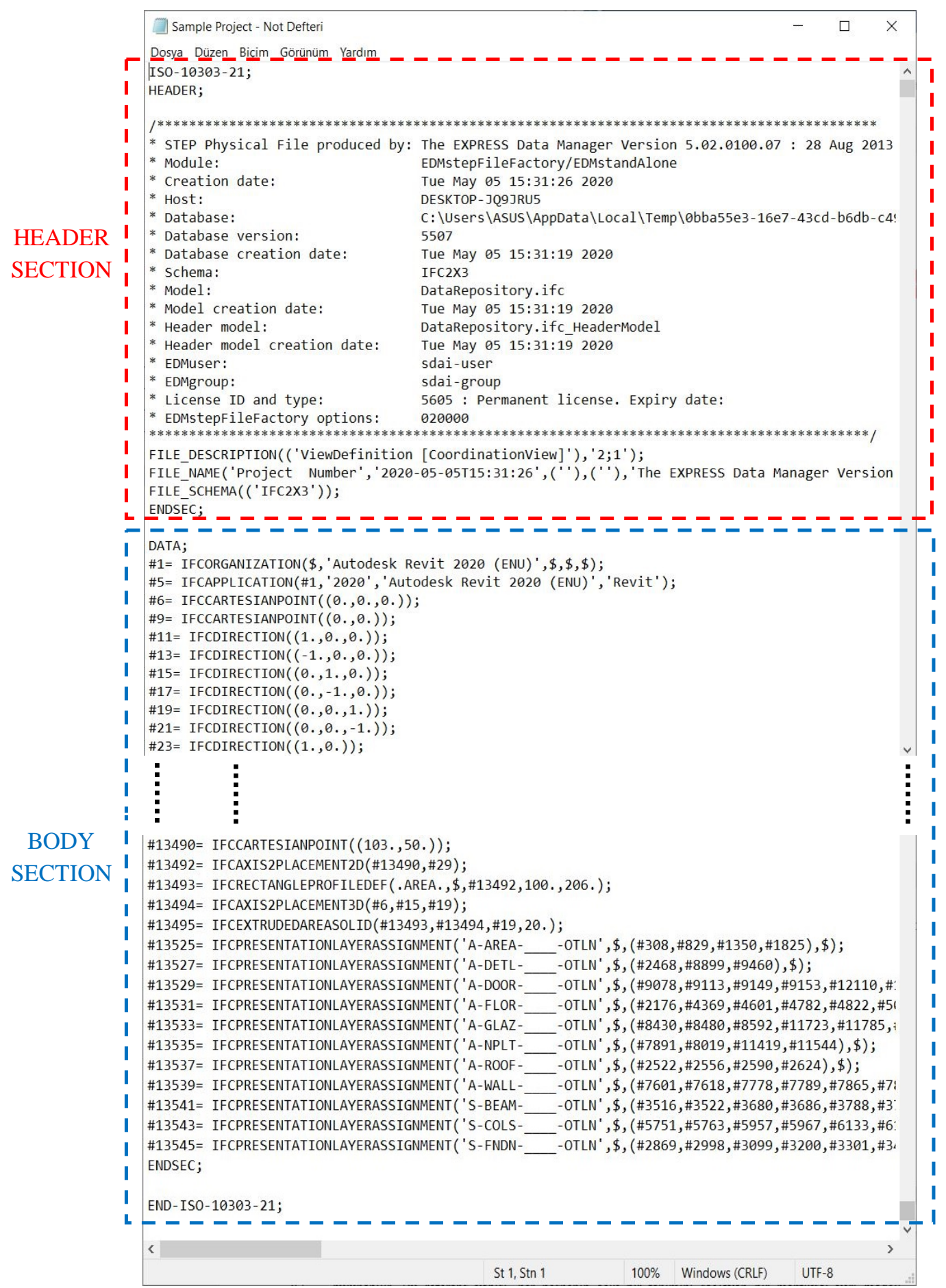

Fig. 7. Plain text content of IFC-STEP file with “.ifc" extension of the sample building model 
The basic structure of the IFC-STEP file consists of two sections, the header, and the body. The header section contains general information about the IFC version used, the date of creation, etc. belonging to the building model. When the header section of the IFC file of the sample building model shown in Fig. 7 is examined, it is seen that the scheme of the IFC file is in the format of IFC $2 \times 3$. The body section contains information about the geometry and qualities of the building model. In addition, information on how the relationships between each element of the model created are included in this section.

Each line of data in the body part of the IFC file starts with the hash key \#. Data lines are numbered starting from \# 1. There is an IFC entity in each numbered line. There are 13545 data lines in the IFC file of the sample building model shown in Fig. 7. The number of data lines in the IFC file increases according to the number of each building element (column, beam, wall, floor, door, window, roof, stairs, etc.) that makes up the building model, the preference of the material properties of the elements and each process performed in the program. In the BIM program (Revit), each element of the building model and each operation for the design of the model corresponds to an entity in the IFC data file.

The data line formed in the IFC file of a column element of the sample building model is as in Fig. 8. In this data line numbered with \# 5771, the column element of the building model is identified by the IfcColumn entity. In addition, each entity consists of its own attributes. Each section separated by commas between the two parentheses following the entity in the data line defines the attributes of that asset. In Fig. 8, each part separated by a comma between two parentheses after the IfcColumn entity in the data line of the column element defines the attributes of the column element. For example, in Fig. 8, the 5th attribute in the data line \# 5771 contains the information that the column is a rectangular column of $40 \times 50 \mathrm{~cm}$.

Locations that begin with \# between the two parentheses of the IFC entity redirect to the entities on the other lines in the file. In other words, the expression "\# 41" in the 2nd attribute of the IfcColumn entity in Fig. 8 indicates that the information in this attribute is in line 41 . The assets in the referenced lines contain more detailed properties and information on the column object. Entities in the referenced lines can also refer to assets in other lines. This reference structure continues until a logical data model has been generated that provides a clear description of each object. The fact that the IFC scheme includes relationships by referencing is what makes IFC special and powerful [77].

Some relationships between building elements in the IFC file explain how the components of the building come together. Relations include how the spatial structure is formed, grouped, and hierarchical structure. The hierarchical structure shows how a project consists of a site, how a site consists of buildings, how buildings consist of floors, and how floors consist of rooms (spaces). Other relationships link the position and properties of the elements to this spatial structure and to which it belongs. IFC files create a building model hierarchy based on a predefined structure that logically creates the BIM model. An example of IFC's hierarchical structure is given in Fig. 9.

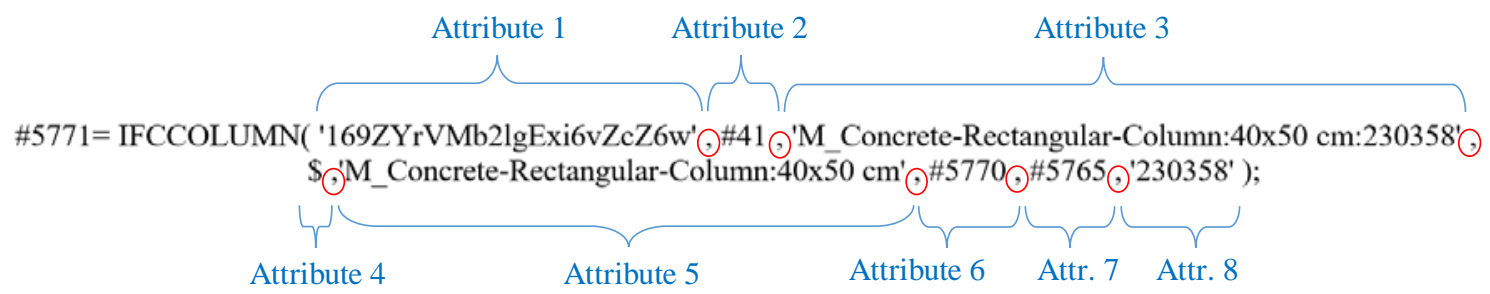

Fig. 8. Data line of IfcColumn entity in IFC file 


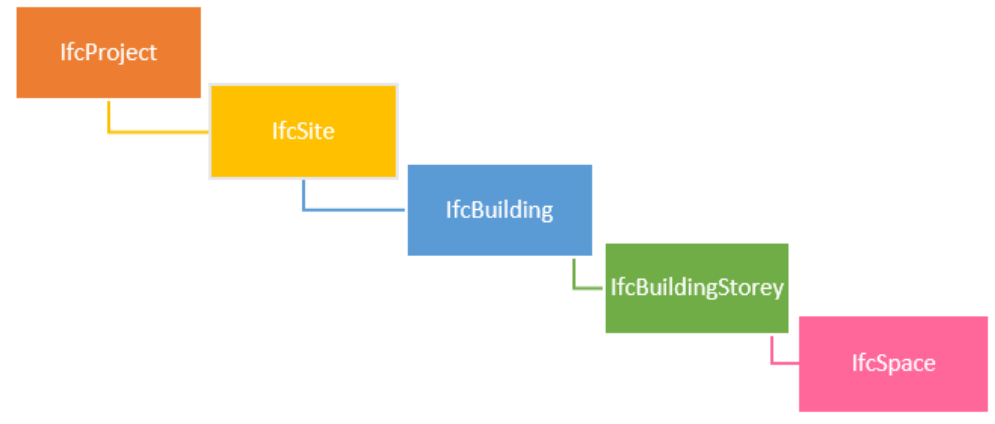

Fig. 9. An example of the IFC hierarchy

A representative view of the breakdown structure (hierarchy) of the sample building model is given in Fig. 10. The sample building consists of two floors with two rooms on each floor of the model. Thanks to this hierarchy of the structure, information on which floors the building consists of and which spaces (rooms) the floors consist of can be accessed via the IFC file.

In the IFC data file, the formation of the project's breakdown structure (hierarchy) is done by the presence of IfcRelAggregates. The definition and properties of the IfcRelaggregates entity are briefly as follows [76]:

- This entity helps collect objects,

- It consists of 6 attributes (parts separated by commas between two parentheses),

- The 5th attribute indicates which object the elements will be collected to,

- The 6th attribute indicates which elements are to be collected.

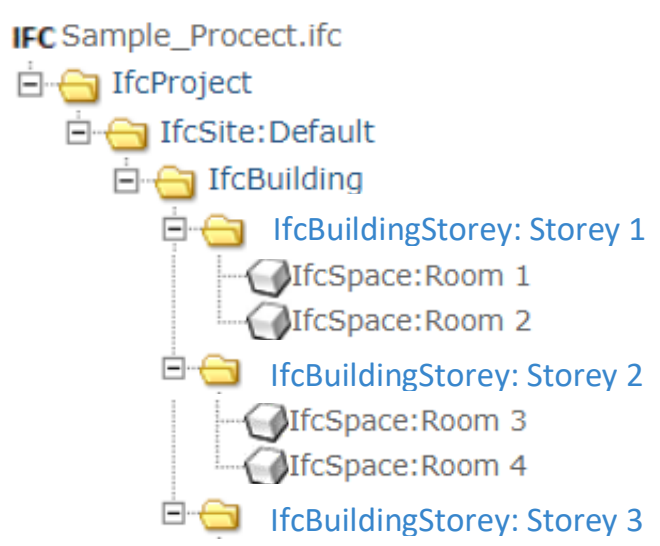

Fig. 10. Representative view of the IFC hierarchy of the sample building model

In the IFC file of the sample building model, the information that the first floor consists of Room 1 and Room 2 is found in the data line \#12796 in order to be an example of the formation of the hierarchy.

\#12796= IFCRELAGGREGATES('1vK3KfqgSHqv5Y00A6FnIY',\#41,\$,\$,\#127,(\#1354,\#1829));

Data line \#12796 contains the IfcRelaggregates entity. This entity, by definition, helps to collect the objects in its 6th attribute (\#1354, \#1829) into the object of the 5th attribute (\#127). The object in the 5th attribute refers to the IfcBuildingStorey entity defined in data row \#127. The IfcBuildingStorey entity is used to define the floors of the building in the IFC file. In the 8th attribute of the IfCBuildingStorey entity in data row \#127, this floor is "Storey 1 " as seen in the data row.

\#127= IFCBUILDINGSTOREY('1XY1wKHp96PaZ2rMvu16R',\#41,'Level 1',\$,'Level:8mm Head',\#125,\$,'Storey 1', .ELEMENT.,0.);

The objects in the 6th attribute of the IfcRelaggregates entity in data line \#12796 refer to data line \#1354 and \#1829. There is an If Space entity in these referenced lines. The IfcSpace entity defines the rooms of the building. From the 8th attribute of the IfcSpace entity, the name of the room is reached (Room 1, Room 2). 
\#1354= IFCSPACE('169ZYrVMb2lgExi6vZcZvq',\#41,'1',\$,\$,\#1192,\#1352,'Room 1', .ELEMENT.,.INTERNAL.,\$); \#1829= IFCSPACE('169ZYrVMb2lgExi6vZcZvm',\#41,'2',\$,\$,\#1637,\#1827,'Room 2',.ELEMENT.,.INTERNAL.,\$);

In the IFC data file, the numerical information and characteristics of each element belonging to the building being modeled are accessed by the presence of IfcRelDefinesByProperties. The definition and properties of the IfcRelDefinesByProperties entity are as follows in short [76]:

- This entity defines the property set definitions and relationships between objects,
- It consists of 6 attributes (parts separated by commas between two parentheses),

- The 5th attribute indicates which objects or properties will be collected to,

- The 6th attribute refers to the target object or set of properties to be applied to the objects.

In the IFC file of the sample building model, information on how to reach the field value of "Room 1" located on the 1st floor, for example, is found in the data line $\# 1360$.

\#1360= IFCRELDEFINESBYPROPERTIES('1G4SYd3p9F2hc9BXsTlvyX',\#41,\$,\$,(\#1354),\#1358);

Data line \#1360 contains the entity IfcRelDefinesByProperties.

The IfcRelDefinesByProperties entity defines the object in the 5th attribute, the information of the object in the 6th attribute. The object in the fifth attribute refers to data line \#1354. In the data line \#1354, there is an IfcSpace entity. The object in the 6th attribute refers to the data line \#1358. There is an IfcElementQuantity entity in data line \#1358. In short, the IfcRelDefinesByProperties entity in data row \#1360 means that the IfcSpace entity in data row \#1354 has properties in the IfcElementQuantity entity in data row \#1358.

The IfcElementQuantity entity in data row \#1358 refers to the "GSA Space Areas" value, and its numerical value is in the presence of \#1357 IfcQuantityArea. The presence of IfcQuantityArea in line \#1357 indicates that the numerical value is “21.16”.

\#1354= IFCSPACE('169ZYrVMb2lgExi6vZcZvq',\#41,'1',\$,\$,\#1192,\#1352,'Room 1',.ELEMENT.,.INTERNAL.,\$);

\#1358= IFCELEMENTQUANTITY('0S5Ul6kvAEQ3iXLvbcv',\#41,'GSA Space Areas',\$,'GSA BIM Area',(\#1357))

\#1357= IFCQUANTITY AREA('GSA Space Areas',\$,\$,21.16);

Thanks to an algorithm based on these examinations, these data can be easily exported from the IFC file with a programming language. Thus, the data of the model, which is the most important step for Automatic Code Compliance Checking, will be obtained.

\subsection{Code compliance checking}

In order to compare the rules obtained in the legislation with a project drawn up in a BIM-based program and to check whether the project is in compliance with the legislation, the following steps should be followed:

1. Rules are determined in the relevant legislation.

2. The IFC file of the drawn project is exported from the BIM program.
3. The hierarchy of the parameters that define the stated rules in the IFC file is determined.

4. Depending on the specified hierarchy, the script is written so that the data can be exported from the IFC file.

5. If it is necessary to apply mathematical operations to the data obtained from the IFC file, these are performed.

6. The results are compared with the rules from the regulation.

7. The report is prepared.

In order to show the operation of the above algorithm, the algorithm was followed manually using a sample. In the first place, it is necessary to determine the rules from the legislations regarding the buildings. The main legal regulations in Turkey 
are as follows: Zoning Law, Building Bylaws, Parking Regulations etc. In this study, the criteria that the storey heights of the buildings must meet in the Turkish Building Bylaws are taken into consideration. The 28th article of this legislation on storey heights is given below [78]:

ARTICLE 28- (1) If the storey heights have not been determined more in the implementation zoning plan, the maximum from one the slab top elevation to the other slab top elevation;

a) In the trade zones; 4.50 meters on ground floors, 5.50 meters on ground floors with mezzanines; 4.00 meters on other floors,

b) In mixed areas where trade is also possible; 4.50 meters on ground floors, 5.50 meters on ground floors with mezzanines; other floors are 3.60 meters if the residence is outside, 4.00 meters outside the residence,

c) 3.60 meters on ground and normal floors in residential areas,

c) In the residential areas that can be traded on the ground floor, 4.50 meters on the ground floors, 5.5 meters on the ground floors and 3.60 meters on the other floors,

can be accepted and applied.

According to Article 28, it is checked whether the storey heights are suitable in the building taken as an example. The storey names of the sample building model and the appearance of the storey heights are given in Fig. 11.

The IFC file of the sample building model was obtained by exporting from the Revit program. The view of the IFC file is given in Figure 7 under the "6. Implementation" title. For comparison, the name and height information of the storeys must be obtained from this IFC file. Therefore, the hierarchy of receiving this information needs to be determined. The storeys of the sample building model are defined in the IFC file with the entities of IfcBuildingStorey. The 3rd and 8th attribute of the IfcBuildingStorey entity is located between the two brackets has the name of the storey. In the last attribute, the relevant storey has elevation value. Elevation value shows the height value according to the zero level of the related storey. In other words, it does not show the storey height of that floor. From the elevation value of the above floor, the elevation value of the examined floor is subtracted to obtain the storey height of the examined floor. In the IFC file of the model, the name and height values of the lines defined by the presence of IfcBuildingStorey can be easily taken out of the file with a script based on this examination. Afterwards, code compliance checking can be made for accordance with the relevant regulation article. IfcBuildingStorey entities formed in the IFC file of the sample building model are given below.

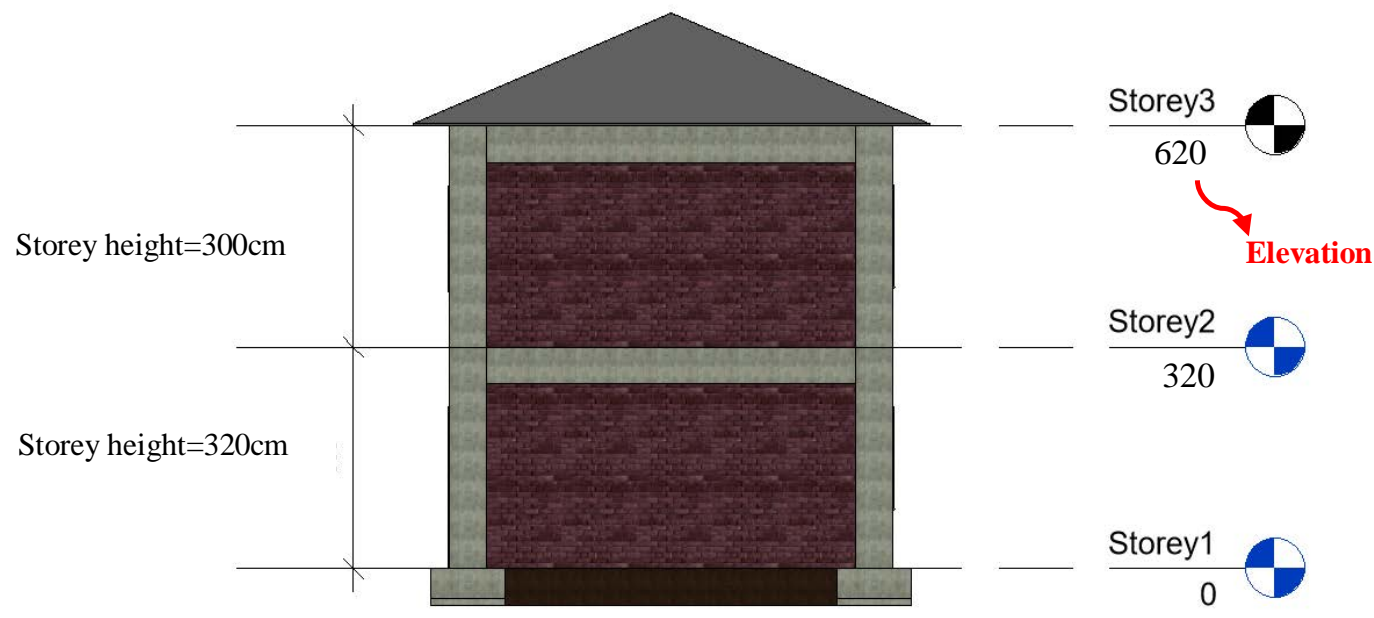

Fig. 11. View of the sample building model 
\#127= IFCBUILDINGSTOREY('1XY1wKHp96PRaZ2rMvu16R',\#41,'Storey1',\$,'Level:8mm Head',\#125,\$,'Storey1', .ELEMENT.,0.00);

\#133= IFCBUILDINGSTOREY('1XY1wKHp96PRaZ2rMvu1oz',\#41,'Storey2',\$,'Level:8mm Head',\#132,\$,'Storey2', .ELEMENT.,320.00);

\#139= IFCBUILDINGSTOREY('1XY1wKHp96PRaZ2rMvuwpi',\#41,'Storey3',\$,'Level:8mm Head',\#138,\$,'Storey3', .ELEMENT.,620.00);

In accordance with the above information, the name and height values of the storeys of the building model will be easily obtained with the script to be written. The model is a building built in residential areas and consists of two floors, namely first floor (Storey 1) and normal floor (Storey2). With the help of a control panel to be created as in Table 3 according to sub-clause c of the 1 st subarticle of Article 28 of the Turkish Building Bylaws, the compliance of the storey heights of the building model according to the regulation can be checked. These reviews show that the IFC file structure is directly related to automatic code compliance checking.

\section{Conclusion}

Among AEC industries, BIM is considered to be the most effective platform for information exchange for design, construction and facility management activities. BIM is a common requirement for interoperability. BIM offers new opportunities for anyone involved in a building design and construction project to make well-informed project decisions, communicate better, optimize workflows and improve documentation. Thus, it increases the efficiency and accuracy of the design and construction of a building planned to be constructed. Also, most of the tools used in design and construction projects support the export or import of file formats of BIM programs. The information of the building elements of the models obtained from BIM-based programs is created in the form of IFC entities within the IFC file format. The IFC file format is a data model used to define building data and geometry in building disciplines and stages of the building life cycle. This information can be easily transferred between different software. In this way, it also creates a base for systems that allow automatic control of compliance with building regulations and standards.

In this study, IFC file format of an exemplary building model designed with a BIM-based program is examined. It has been determined where and in which order the data needed to perform the automatic code compliance checking is in the file. This information can be exported from the IFC file by using an algorithm and using a programming language. Thus, the data of the model, which is the most important step for automatic code compliance checking, can be obtained. As a result, it has been demonstrated that the data that will enable automatic code compliance checking can be obtained from the IFC file format with this method and that the IFC file structure is related to automatic code compliance checking.

\section{Declaration of conflicting interests}

The author(s) declared no potential conflicts of interest with respect to the research, authorship, and/or publication of this article.

Table 3. Control of storey heights according to legislation values

\begin{tabular}{lccc}
\hline \multicolumn{3}{c}{ Storey heights - code compliance checking table } \\
\hline Storey name & $\begin{array}{c}\text { Storey heights } \\
(\mathrm{cm})\end{array}$ & Rule in legislations & Compliance Check \\
\hline Storey1 & 320 & The storey height must be $<360 \mathrm{~cm}$ & Compliance \\
Storey2 & 300 & The storey height must be $<360 \mathrm{~cm}$ & $\checkmark$ \\
\hline
\end{tabular}




\section{References}

[1] Hjelseth E (2015). Public BIM-based model checking solutions: Lessons learned from Singapore and Norway. WIT Transactions on the Built Environment 149: 421-436.

[2] Borrmann A, Konig M, Koch C, Beetz J. Building Information Modeling-Technology Foundations and Industry Practice. Springer, Switzerland, 2018.

[3] Nisbet N, Wix J, Conover D. The future of virtual construction and regulation checking. In: Brandon PS, Kocatürk T. (ed.) Virtual futures for design, construction \& procurement. Oxford: Blackwell Publishing Ltd, 2009, chapter 17.

[4] Abanda FH, Vidalakis C, Oti AH, Tah JHM (2015). A critical analysis of building information modelling systems used in construction projects. Advances in Engineering Software 90: 183-201.

[5] Taşlı Pektaş Ş (2009). Building information modeling applications in architecture (Mimarlıkta yapı bilgi modellemesi uygulamaları). Mimarlık 346: 81-84.

[6] Howell I, Batcheler B (2005). Building information modeling two years later-huge potential, some success and several limitations. The Laiserin Letter.

[7] Fleming WS. BIM modelling for structural analysis. MSc Thesis, Poznan University of Technology/Tampere University of Technology, 2016.

[8] Haagenrud SE, Björkhaug L, Wix J, Trinius W, Huovila P. EU-project stand-inn-integration of standarts for sustainable construction into business processes using BIM/IFC. ECPPM 2008 eWork and eBusiness in Architecture, Engineering and Construction, 10-12 September 2008, Sophia Antipolis, France.

[9] Türky1lmaz ME. A conceptual collaborative environment based on ifc data model. PhD Thesies, Y1ldiz Technical University, 2010

[10] Froese TM (2010) The impact of emerging information technology on project management for construction. Automation in Construction 19(5): 531-538.

[11] Bryde DJ, Broquetas M, Volm JM (2013). The project benefits of building information modelling (BIM). International Journal of Project Management 31(7): 971-980.

[12] Heigermoser D, Soto BG, Abbott ELS, Chua DKH (2019). BIM-based last planner system tool for improving construction project management. Automation in Construction 104: 246-254.
[13] Fitz DV, Saleeb N (2019). Examining the quality and management of non geometric building iinformation modelling data at project hand-over. Architectural Engineering and Design Management 15(4): 297-310.

[14] Arayici Y, Onyenobi T, Egbu C (2012). Building information modelling (BIM) for facilities management (FM): The mediacity case study approach. International Journal of 3-D Information Modeling 1(1): 55-73.

[15] [Bortoluzzi B, Efremov I, Medina C, Sobieraj D, McArthur JJ (2019). Automating the creation of building information models for existing buildings. Automation in Construction 105, 102838. http://doi.org/10.1016/j.autcon.2019.102838

[16] Becerik-Gerber B, Jazizadeh F, Li N, Calis G (2012). Application areas and data requirements for BIM-enabled facilities management. J Constr Eng Manag 138: 431-442.

[17] Jupp J, Awad R. BIM-FM and information requirements management: missing links in the AEC and FM interface. IFIP International Conference on Product Lifecycle Management, Jul 10 2017, Springer, Cham.

[18] Pärn EA, Edwards DJ, Draper R. A case study of building information modelling enabled information totem for operations and maintenance integration. CIB World Congress, 2016, Tampere, Finland.

[19] Hsieh CC, Liu CY, Wu PY, Jeng AP, Wang RG, Chou CC (2019). Building information modeling services reuse for facility management for semiconductor fabrication plants. Automation in Construction 102: 270-287.

[20] Ahmad T, Thaheem MJ (2017). Developing a residential building-related social sustainability assessment framework and its implications for BIM. Sustainable Cities and Society 28: 1-15.

[21] Solla, M, Ismail LH, Shaarani ASM, Milad A (2019). Measuring the feasibility of using of BIM application to facilitate GBI assessment process. Journal of Building Engineering 25, 100821.

[22] Lewis AM, Valdes-Vasquez R, Clevenger C (2019) Understanding the perceived value of using BIM for energy simulation. Journal of Green Building 14(1): 79-92.

[23] Maciel ACF, Carvalho MT (2019). Operational energy of opaque ventilated facades in Brazil. Journal of Building Engineering 25, 100775.

[24] Singh P, Sadhu A (2019). Multicomponent energy assessment of buildings using Building Information 
Modelling. Sustainable Cities and Society 49, 101603.

[25] Ahmad T, Thaheem MJ (2018). Economic sustainability assessment of residential buildings: A dedicated assessment framework and implications for BIM. Sustain Cities Soc 38: 476491.

[26] Carvalho JP, Braganca L, Mateus R (2019). Optimising building sustainability assessment using BIM. Automation in Construction 102: 170182.

[27] Irizarry J, Karan EP, Jalaei F (2013). Integrating BIM and GIS to improve the visual monitoring of construction supply chain management. Automation in Construction 31: 241-254.

[28] Al-Saggaf A, Jrade A. Benefits of integrating BIM and GIS in construction management and control, 5th International Construction Specialty Conference of the Canadian Society for Civil Engineering (ICSC), 8-10 Jun 2015, Vancouver, British Columbia.

[29] Amirebrahimi S, Rajabifard A, Mendis P, Ngo T (2016). A framework for a microscale flood damage assessment and visualization for a building using BIM-GIS integration. International Journal of Digital Earth 9(4): 363-386.

[30] Zhu JX, Wang XY, Wang P, Wu ZY, Kim MJ (2019). Integration of BIM and GIS: geometry from IFC to shapefile using open-source technology. Automation in Construction 102: 105-119.

[31] Aksamija A (2018) Methods for integrating parametric design with building performance analysis. ARCC Conference Repository, Sep 25 2018.

[32] Asl MR, Bergin M, Menter A, Yan W (2014). BIMbased parametric building energy performance multi-objective optimization, Retrived from: http://papers.cumincad.org/cgi-

bin/works/paper/ecaade2014_224 Date of access: 26.08.2019.

[33] Kensek K (2015). Visual programming for building information modeling: energy and shading analysis case studies. Journal of Green Building 10(4): 2843.

[34] Eastman C, Lee JM, Jeong YS, Lee JK (2009). Automatic rule-based checking of building designs. Automation in Construction 18(8): 1011-1033.

[35] Fan SL, Chi HL, Pan PQ (2019). Rule checking Interface development between building information model and end user. Automation in Construction 105, 102842.
[36] Ismail AS, Ali KN, Iahad NA. A review on BIMbased automated code compliance checking system. 5th International Conference on Research and Innovation in Information Systems (ICRIIS 2017): Social Transformation Through Data Science, 16-17 July 2017, Langkawi, Malaysia.

[37] Fan SL, Chi HL, Pan PQ (2019). Rule checking interface development between building information model and end user. Automation in Construction 105, 102842.

[38] Maçka Kalfa S (2018). Building information modeling (BIM) systems and their applications in Turkey. Journal of Construction Engineering, Management \& Innovation 1(1): 55-66.

[39] Charef R, Emmitt S, Alaka H, Fouchal F (2019). Building information modelling adoption in the european union: an overview. Journal of Building Engineering 25, 100777.

[40] Öğreten B (2020). What are BIM Software? Retrived from: https://www.bimteknoloji.com/fikir/bim-

yazilimlari-hangileridir/ Date of access: 30.04.2020

[41] Greenwood D, Lockley S, Malsane S, Matthews J (2010). Automated compliance checking using building information models. Retrived from: http://nrl.northumbria.ac.uk/6955/1/Automated_co mpliance_checking_using_building_information.p df Date of access: 18.04.2020

[42] Yunxue L, Martins JP (2015). Automated codechecking of BIM models. Retrived from: https://paginas.fe.up.pt/ gequaltec/w/images/Final _dissertation-Yunxue_Li.pdf Date of access: 15.04.2020

[43] Nawari ON. Building information modelingautomated code checking and compliance processes. Taylor \& Francis Group, 2018

[44] Raslan R, Davies M (2006). An analysis of industry capability for the implementation of a softwarebased compliance approach for the UK Building Regulations 2006. Building Services Engineering Research and Technology 31(2): 141-162.

[45] Han CS, Kunz JC, Law KH (1998). A hybrid prescriptive/performance based approach to automated building code checking. International Computing Congress. Retrived from: http://eil.stanford.edu/publications/chuck_han/981 0\%20ICC.pdf Date of access: 11.04.2020

[46] Han CS, Law KH, Latombe J, Kunz JC (2002). A performance-based approach to wheelchair 
accessible route analysis. Advanced Engineering Informatics 16(1): 53-71.

[47] Fenves SJ (1966). Tabular decision logic for structural design. J. Structural Engn 9(92): 473490.

[48] Lopez LA, Wright RN (1985). Mapping principles for the standards interface for computer aided design (NBSIR 85-3115). Gaithersburg, MD: National Bureau of Standards. Retrived from: https://nvlpubs.nist.gov/nistpubs/Legacy/IR/nbsir8 5-3115.pdf Date of access: 14.04.2020

[49] Lopez L, Elam S, Reed K (1989). Software concept for checking engineering designs for conformance with codes and standards. Engineering with Computers 5(2): 63-78.

[50] Garrett JH, Fenves SJ (1987). A knowledge-based standard processor for structural component design. Engineering with Computers 2(4): 219-238.

[51] Yabuki N, Law KH (1992). An integrated framework for design standards processing. Technical Report 67, Center for Integrated Facility Engineering, Stanford University, Stanford, CA.

[52] Kiliccote H. A standards processing framework. PhD Thesis, Carnegie Mellon University, 1996.

[53] Vassileva S (2000). Constructing integrated client/server framework for operative checking of building code. Retrived from: https://pdfs.semanticscholar.org/9758/994604b5cb 6c5c2e47e40e003bdf3920514a.pdf Date of access: 12.04.2020

[54] Fenves S, Goel S, Gaylord E (1969). Decision Table Formulation of the 1969 AISC Specification. Urbana. Retrieved from http://babel.hathitrust.org/cgi/pt?id=wu.89038865 689;view=1up;seq=9 Date of access: 28.03.2020

[55] Noland JL, Bedell R (1985). Automated checking of simply-supported prismatic reinforced concrete beams for compliance with code requirements. National Bureau of Standards Special Report 7182.

[56] Pesquera C, Hanna S, Abel J (1984). Advanced graphical CAD system for 3D steel frames. Computer Aided Design in Civil Engineering 8391.

[57] Jaeger S, Harelik L (1985). Automation of the building code compliance. National Bureau of Standards Special Report. US Department of Commerce.

[58] Kähkönen K, Björk BC (1987). Computerization of building standards. Espoo, Finland: Technical Research Centre of Finland.
[59] Fiatech (2012). AutoCodes Project: Phase 1; Proofof-concept final report. Retrieved from: https://constructech.com/wpcontent/uploads/2014/09/Whitepaper_FIATECH_ AutoCodes.pdf Date of access: 25.03.2020

[60] Hakim M, Garret J (1993). A description logic approach for representing engineering design standards. Engineering with Computers 9(2): 108124.

[61] Eastman C, Teicholz P, Sacks R, Liston K. BIM Handbook: A Guide to Building Information Modeling for Owners, Managers, Designers, Engineers and Contractors. John Wiley \& Sons, Inc, New Jersey, 2011.

[62] Eastman C (1999). Building product models: computer environments supporting design and construction. ISBN:0849302595, CRC Press.

[63] McPartland R (2017). What is IFC? Retrieved from: https://www.thenbs.com/knowledge/whatis-ifc Date of access: 15.03.2020

[64] ISO 16739-1:2018 Retrieved from: https://www.iso.org/standard/70303.html Date of access: 21.02.2020

[65] BuildingSMART International (2020). Industry Foundation Classes (IFC)-an introduction. Retrieved from: https://technical.buildingsmart.org/standards/ifc/ Date of access: 22.04.2020

[66] BuildingSMART International (2015). Model support group of buildingSMART international. Retrieved from: http://www.buildingsmarttech.org/about-us/msg Date of access: 16.02.2020

[67] ISO10303-21:2016 Retrieved from: https://www.iso.org/standard/63141.html Date of access: 15.03 .2020

[68] BuildingSMART International (2020). The importance of Industry Foundation Classes in Building Information Modelling. Retrieved from: https://blog.buildingsmart.org/blog/importantifc Date of access: 21.02.2020

[69] BuildingSMART International (2020). IFC Formats. Retrieved from: https://technical.buildingsmart.org/standards/ifc/if c-formats/ Date of access: 19.03.2020

[70] Wikipedia (2020). Industry Foundation Classes. Retrieved from: https://en.wikipedia.org/wiki/Industry_Foundation _Classes\#History Date of access: 12.03.2020

[71] BuildingSMART International (2020). IFC Specifications Database. Retrieved from: https:/technical.buildingsmart.org/standards/ifc/if 
c-schema-specifications/ Date of access: 19.03.2020

[72] Autodesk (2018). Revit IFC manual. Detailed instructions for handling IFC files. Retrieved from: https://damassets.autodesk.net/content/dam/autode sk/draftr/2528/180213_IFC_Handbuch.pdf Date of access: 04.06.2020

[73] BuildingSMART International (2020). Retrieved from: https://www.buildingsmart.org/ Date of access: 16.02 .2020

[74] Areo (2016). What is IFC and what do you need to know about it? Retrieved from: https://blog.areo.io/what-is-ifc/ Date of access: 26.02.2020

[75] Hooper E, (2018). BIMBlog. IFC (industry foundation classes)-an introduction for autodesk revit users. Retrieved from: https://bimblog.bondbryan.co.uk/ifc-industryfoundation-classes-an-introduction-for-autodeskrevit-users/\#more-7365 Date of access: 04.02.2020

[76] BuildingSMART International (2020). IFC4 specification. Retrieved from: http://standards.buildingsmart.org/MVD/RELEAS E/IFC4/ADD2_TC1/RV1_2/HTML/ Date of access: 04.05.2020

[77] Hooper E. BIMBlog. IFC (industry foundation classes)-layers and classification in autodesk revit. Retrieved from: https://bimblog.bondbryan.co.uk/ifc-industryfoundation-classes-layers-and-classification-inautodesk-revit/\#more-7576 Date of access: 25.04.2020

[78] Turkish Building Bylaws (2020). Retrieved from: https://www.mevzuat.gov.tr/mevzuat?MevzuatNo $=23722 \&$ MevzuatTur=7\&MevzuatTertip=5 Date of access: 24.06.2020 